\title{
Organic Acids Concentration in Citrus Juice from Conventional versus Organic Farming
}

\author{
A.M. Duarte, D. Caixeirinho, M.G. Miguel, \\ V. Sustelo, and C. Nunes \\ Universidade do Algarve/ ICAAM, \\ Edifício 8, Campus de Gambelas, \\ 8005-139 Faro, Portugal
}

M. M. Fernandes and A. Marreiros, Direcção Regional de Agricultura e Pescas do Algarve,

Patacão, 8000 Faro, Portugal

Keywords: Citric acid, malic acid, tartaric acid, ascorbic acid, oxalic acid and malonic acid, clementine, fruit quality, orange, mandarin, lemon.

\begin{abstract}
Every day consumers make choices about what to eat and ask themselves "Should I be buying organic food?" For producers, is very important to have technical information about the quality of organic products. It can facilitate to demonstrate the quality of organic products, in comparison with conventional ones.

The purpose of our work was to compare internal and external characteristics of citrus, produced in organic versus conventional farming. The study was carried out in the south of Portugal. Fruits of different orchards have been harvested and submitted to physical and chemical analyses, as well as to a sensorial test. The analyses showed that the farming system affected fruit quality. Special attention was paid to the concentration of vitamin $C$, a compound which plays an important role in human health. Fruits from organic farming had a higher level of vitamin $\mathbf{C}$, compared with fruits from conventional production. However, this result was not obtained in all cultivars. The concentration of other organic acids was also evaluated. Results showed clear differences between cultivars and between the two farming systems. In most cases, concentration of organic acids was higher in the citrus fruits from organic farming.
\end{abstract}

\section{INTRODUCTION}

The intensification of agriculture that occurred over much of the twentieth century and this first decade of XXI century has increased the productivity of the orchards but left out many aspects of fruit quality, including the content of substances beneficial to human health.

Organic farming seeks to be an alternative to intensive agriculture and produce food more beneficial to human health. However, organic food is often more expensive and consumers have questions about whether the additional cost is offset by a higher actual quality of these products.

The organic acids contained in fruits are one of the important factors influencing fruit flavour and are of vital importance to human health. The importance of ascorbic acid (vitamin C) was demonstrated long ago (Sauberlich, 1994). Several studies emphasize the importance of other organic acids such as citric, malic, tartaric and other. Citric acid is important in prevention and elimination of kidney stones, so lemons and limes, due to high concentration of this acid, can be used as a therapy against this disease (Penniston et al., 2007). Malic acid possesses many health-related benefits such as boosting immunity, 
maintaining oral health, reducing the risk of poisoning from a build-up of toxic metals, promoting smoother and firmer skin and helps reducing symptoms of fibromyalgia (Abraham and Flechas, 1992). On the other hand, oxalic acid is considered an "undesired compound" (Franceschi and Horner, 1980; Webb, 1999; Perera et al., 1990).

Eighty percent of all citrus produced in Portugal is grown in Algarve. It is important to know whether, in this region, the citrus fruit produced in organic farming have a higher level of quality compared with conventional agriculture.

Several reviews about comparing these two farming systems are available (Woese et al., 1997; Brandt and Mølgaard, 2001; Worthington, 2001; Bourn and Prescott, 2002; Bordeleau et al., 2002; Raigon, 2007) and the conclusions are far from coincident. Some of the authors did not find significant differences between conventional and organic products (Bourn and Prescott, 2002); while others concluded that food produced by organic farming had a greater quality, compared to that from conventional farming systems (Woese et al., 1997; Brandt and Mølgaard, 2001; Worthington, 2001; Bordeleau et al., 2002; Raigon, 2007).

The effect of the production system on fruit quality was already studied in some citrus (Tarozzi et al., 2006; Lester et al., 2007; Pérez-López et al., 2007; Raigon, 2007; Beltrán-González et al., 2008). In general, citrus fruits produced in organic farms had greater juice percentage (Lester et al., 2007), and mineral (Ca, $\mathrm{Mg}, \mathrm{K}, \mathrm{Na}, \mathrm{Fe}, \mathrm{Cu}, \mathrm{Mn}$ and $\mathrm{Zn}$ ) concentration in the juice (Pérez-López et al., 2007) than those produced by conventional farming systems. If organic citrus were to have a greater organic acids concentration, it might be an important factor to increase demand of fruits from this management system.

A greater ascorbic acid content in citrus from organic compared with conventional farming systems was reported by Tarozzi et al. (2006) for the red orange cultivar 'Tarocco', by Lester et al. (2007) for the grapefruit cultivar 'Rio Red' and by Raigón (2007) for the mandarin cultivars 'Nules' and 'Okitsu' and orange cultivars 'Newhall' and 'Navelina'. In the present work, we compared 18 different citrus types grown either in organic or conventional (integrated) farming, under similar environmental conditions, to investigate the influence of these two management systems on the organic acids content in the fruit juice.

\section{MATERIALS AND METHODS}

This research work was carried out on 18 citrus cultivars: 'Valencia late', 'Baía', 'Dalmau', 'Newhall', 'Lanelate' and 'Rohde' oranges; 'Fina', 'Hernandina', 'Fortune', 'Fremont', Ortanique', 'Tangera' 'Setubalense', 'Nules' and 'Nova' mandarin or mandarin type cultivars; two hybrids between Citrus deliciosa and Citrus nobilis ('Encore' and 'Wilking') and the 'Lisboa' lemon. Each cultivar was sampled in triplicate (at least 20 fruits per replicate), at commercial maturity, from an organic orchard and in a conventional orchard with integrated production practices. Paired orchards were located close to each other, with trees grafted on the same rootstock and of about the same age to allow a valid comparison of organic versus conventional fruits.

All orchards considered as organic farming were managed according to statutory European Union regulations regarding organic farming. In some organic orchards, there was no application of fertilizers in the last five years, while in others fertilization was carried out with authorized fertilizers. In conventionally managed orchards, mineral fertilizers were applied throughout the vegetative cycle of the trees. 
Fruit samples were submitted to physical and chemical analyses within 24 hours after harvest. Fruits were weighed and measured individually. Juice extraction was done by using a hand operated juice extractor. After extraction, juice was filtered and used for different physico-chemical analyses. Part of the filtered juice was immediately cooled and stored at $-20^{\circ} \mathrm{C}$ until organic acid analyses were made. Organic acids were measured as described previously (Miguel et al., 2006), by HPLC (Beckman) equipped with a System Gold Programmable Detector Module 166-UV-Vis (Beckman Coulter, USA), using a Purospher RP-18 column ( $25 \mathrm{~cm} \times 0.4 \mathrm{~cm} ; 5 \mu \mathrm{m}$ particle size). The mobile phase was $20 \mathrm{mM} \mathrm{NaH} \mathrm{PO}_{4}$ (pH 2.7 with orto-phosphoric acid), with a flow rate of $1 \mathrm{ml} / \mathrm{min}$. The volume of each injection was $20 \mu 1$.

The data were subjected to analysis of variance (ANOVA) and means were compared by using a t-test.

\section{RESULTS AND DISCUSSION}

Citric acid was by far the most abundant organic acid in almost all cultivars (Table 1). Only in the case of 'Setubalense' mandarin it was not. The concentration of citric acid was almost always higher in fruits from organic production. Only in 'Fortune' mandarin, the concentration of citric acid was higher in fruits from conventional agriculture. In previous studies, higher levels of citric acid in organic fruits versus conventional were found in peaches (Carbonaro et al., 2002).

Ascorbic acid concentration in the juice was generally higher in citrus fruits produced in the organic orchards (Table 1). However, this difference was not detected in all cultivars included in this study. In 'Valencia late' and 'Baía' oranges the concentration of ascorbic acid was higher in the juice of the fruits from organic farming, but in other orange cultivars ('Dalmau', 'Newhall', 'Lanelate' and 'Rohde') no differences were detected between the fruits from different production systems.

Some of the mandarin or mandarin type cultivars ('Fina', 'Hernandina', 'Fortune', 'Fremont', Ortanique' and 'Tangera') had higher ascorbic acid concentration in the organic farming fruits, but in the two hybrids between Citrus deliciosa and Citrus nobilis ('Encore' and 'Wilking') the opposite was true. No statistically significant differences were detected in 'Setubalense', 'Nules' and 'Nova' mandarins, as well as in 'Lisboa' lemon. Our results do not contradict those obtained previously with 'Rio Red' grapefruit and 'Tarocco' red oranges, but show that enhanced vitamin $\mathrm{C}$ content is not always associated with organic farming, but depends strongly on citrus species and cultivar. Carbonaro et al., (2002) found an increase in ascorbic acid content in peaches from organic farming but no differences were found in pear, showing that this observation may be valid for other types of fruit.

Comparing different organic acid contents between organic versus conventional farming, no conclusive differences were found in strawberry (Hakala et al., 2002), pears (Carbonaro et al., 2002) and cabbage (Sousa et al., 2005). Soups prepared from organically cultivated vegetables had almost six times as much salicylic acid than conventional soups (Baxter et al., 2001).

Malic acid was present in significant amounts in all analysed citrus fruits. In most cultivars, the concentration of malic acid was higher in fruits coming from organic farming. Exceptions were the 'Fortune' mandarin and 'Rohde' orange.

The concentration of tartaric acid, showed no significant differences between the two modes of production in many cultivars. In the case of cultivars 'Nova', 'Fremont', 'Fina', 'Rohde', 'Baía' and 'Dalmau, ' the superiority of organic farming was statistically 
significant. Only in 'Valencia late' the concentration of tartaric acid was higher in fruits of conventional agriculture. Still, comparing the averages of two modes of production in all cultivars, it was found that the fruits of organic farming had more tartaric acid (32.0 $\left.\mathrm{mg} .100 \mathrm{ml}^{-1}\right)$ than those of conventional agriculture $\left(28.2 \mathrm{mg} .100 \mathrm{ml}^{-1}\right)$.

Malonic acid concentration was higher in organic farming in six cultivars and was lower in two. On average, across all cultivars malonic acid concentration was higher in fruits from organic agriculture.

With respect to oxalic acid, the organic fruit had a lower concentration in comparison with conventional farming in 'Carvalhais', 'Fortune', 'Encore' and 'Valencia late'. In 'Fremont' mandarin, the concentration was higher in the fruits from organic orchards. In other cultivars, no statistically significant differences were found between the two farming systems. On average, across all cultivars oxalic acid concentration was higher in fruits from conventional farming system.

\section{CONCLUSIONS}

Our results show that under soil, climate and agronomic conditions of the Algarve, citrus grown in organic farming are better producers of organic acids (citric, malic, tartaric, ascorbic and malonic), compared with conventional production. The concentration of oxalic acid was higher in fruits from conventional farming. In both cases response depended on species and cultivar.

\section{ACKNOWLEDGEMENTS}

Thanks to Qta da Figueirinha, Qta da Barragoa, FRUTALGARVE and CITRIPOR for providing the fruits. We thank also Dr. Denise Martins for technical support. This work was supported by two research projects: Agro n 282 - Horticulture in Organic Farming; Interreg III - CITRISAUDE SP5, P120/03 - Cooperação Transfronteiriça "Citrisaude - New post-harvest technologies to improve quality and safety in citrus".

\section{Literature Cited}

Abraham G. and Flechas J., 1992. Management of fibromyalgia: rationale for the use of magnesium and malic acid. J. Nutr. Med; 3:49-59.

Baxter, G.J., Graham, A.B., Lawrence, J.R., Wiles, D., and Paterson, J.R., 2001. Salicylic acid in soups prepared from organically and non-organically grown vegetables. Eur. J. Nutr., 40:289-292.

Beltrán-González, F., Pérez-López, A.J., López-Nicolás, J.M. and Carbonell-Barrachina, A.A. 2008. Effects of agricultural practices on instrumental colour, mineral content, carotenoid composition, and sensory quality of mandarin orange Juice, cv. Hernandina. J. Sci. Food Agric. 88:1731-1738.

Bordeleau, G., Myers-Smith, I., Midak, M. and Szeremeta, A. 2002., Food Quality: A Comparison of Organic and Conventional Fruits and Vegetables. Ecological Agriculture - Den Kongelige Veterinoer- og Landbohøjskole, Dinamarca.

Bourn, D. and Prescott, J., 2002. A comparison of the nutritional value, sensory qualities, and food safety of organically and conventionally produced foods. Crit. Rev. Food Sci. 42:1-34.

Brandt, K. and Mølgaard, J.P., 2001. Organic agriculture: Does it enhance or reduce the nutritional value of plant foods? J. Sci. Food Agric. 81:924-931. 
Carbonaro, M., Mattera, M., Nicoli, S., Bergamo, P. and Cappelloni, M., 2002. Modulation of antioxidant compounds in organic vs conventional fruit peach (Prunus persica L.), and pear (Pyrus communis L.). J. Agric. Food Chem. 50:5458-5462.

Franceschi, V. R. and Horner, H. T., Jr., 1980. Calcium oxalate crystals in plants. Bot. Rev., 46, 361-427.

Hakala, M., Tahvonen, R., Huopalahti, R. and Lapvetelainen, A. 2002. Quality factors of Finnish strawberries. Acta Horticulturae, 567:727-730.

Lester, G.E., Manthley, J.A. and Buslig, B.S., 2007. Organic vs conventionally grown Rio Red whole grapefruit and juice: comparison of production inputs, market quality, consumer acceptance, and human health-bioactive compounds. J. Agric. Food Res. 55:4474-4480.

Miguel, G., Fontes, C., Martins, D., Neves, A. and Antunes, D., 2006. Effects of postharvest treatment and storage time on the organic acid content in Assaria and Mollar pomegranate (Punica granatum L.) fruit. Ital. J. Food Sci., 18: 317-322.

Penniston, K.L., Steele, T.H. and Nakada, S.Y., 2007. Lemonade therapy increases urinary citrate and urine volumes in recurrent calcium oxalate stone formers. Urology; 70(5):856-860.

Perera, C.O., Hallett, I.C., Nguyen, T.T. and Charles, J.C. 1990. Calcium oxalate crystals: The irritant factor in kiwifruit. J. Food Sci.: 55, 1066-1069, 1080.

Pérez-López, A.J., López-Nicolás, J.M. and Carbonell-Barrachina, A.A. 2007. Effects of organic farming on minerals contents and aroma composition of Clemenules mandarin juice. European Food Res. Technol. 225:255-260.

Raigón, M.D., 2007. Alimentos ecológicos, calidad y salud. Junta de Andalucía: Consejería de Agricultura y Pesca, Sociedad Española de Agricultura Ecológica (SEAE), Sevilla.

Sauberlich H.E. 1994. Pharmacology of vitamin C. Annu. Rev. Nutr. 14:371-391

Sousa, C., Valentão, P., Rangel, J., Lopes, G., Pereira, J. A., Ferreres, F., Seabra, R. M. and Andrade, P. B. 2005. Influence of two fertilization regimens on the amounts of organic acids and phenolic compounds of Tronchuda cabbage (Brassica oleracea L. var. costata DC). J. Agric. Food Chem. 53, 9128-9132.

Tarrozi, A., Hrelia, S., Angeloni, C., Morroni, F., Biaggi, P., Guardigli, M., Cantelli-Forti, G. and Hrelia, P. 2006. Antioxidant effectiveness of organically and non-organically grown red oranges in cell culture systems. Eur. J. of Nutr. 45:152-158.

Webb, M. A. 1999. Cell-mediated crystallization of calcium oxalate in plants. Plant Cell, 11, 751-761.

Woese, K., Lange, D., Boess, C. and Boegl, K.W. 1997. A comparison of organically and conventionally grown foods - results of a review of the relevant literature, J. Sci. Food Agric. 74:281-293.

Worthignton, V. 2001. Nutritional quality of organic versus conventional fruits, vegetables and grains. J. Altern. Complem. Med. 7:161-173. 
Table 1. Effect of orchard management on organic acid concentration in the juice of 18 citrus cultivars.

\begin{tabular}{|c|c|c|c|c|c|c|c|c|c|c|c|c|c|}
\hline \multirow{3}{*}{\multicolumn{2}{|c|}{ Cultivars }} & \multicolumn{12}{|c|}{ Organic acid concentration (mg.100 $\left.\mathrm{ml}^{-1}\right)$} \\
\hline & & \multicolumn{2}{|r|}{ Citric } & \multicolumn{2}{|c|}{ Ascorbic } & \multicolumn{2}{|c|}{ Malic } & \multicolumn{2}{|c|}{ Tartaric } & \multicolumn{2}{|c|}{ Malonic } & \multicolumn{2}{|c|}{ Oxalic } \\
\hline & & Conv. & Org. Sign.(1) & Conv. & Org.Sign. & Conv. & Org.Sign. & Conv. & Org.Sign. & Conv. & Org. Sig. & Conv. & Org. Sign. \\
\hline \multirow{11}{*}{ 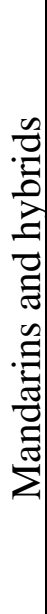 } & Carvalhais & 648 & 839 NS & 29,6 & $48,7 * *$ & 85.8 & 106.7 NS & 60.6 & 59.9 NS & 24.1 & $37.4 * *$ & 13.4 & $9.2 * *$ \\
\hline & Ortanique & 524 & $1009 * *$ & 5,4 & $12,1 *$ & 96.5 & $192.5 * *$ & 10.0 & $13.2 \mathrm{NS}$ & 7.2 & $7.0 \mathrm{NS}$ & 8.3 & $9.5 \mathrm{NS}$ \\
\hline & Nova & 95 & $835 * *$ & 21,7 & $25,8 \mathrm{NS}$ & 97.5 & $179.8 * *$ & 10.5 & $18.9^{* *}$ & 20.6 & 16.3 NS & 10.8 & $9.1 \mathrm{NS}$ \\
\hline & Fremont & 226 & $574 * *$ & 7,2 & 33,0 ** & 86.9 & $165.5 * *$ & 39.2 & $63.4 *$ & 17.7 & $31.6 *$ & 10.0 & $14.9 *$ \\
\hline & Fortune & 966 & $615 *$ & 4,3 & $27,2 * *$ & 152.8 & $101.1 * *$ & 12.6 & $8.2 \mathrm{NS}$ & 10.9 & $23.2 * *$ & 13.9 & $6.0 * *$ \\
\hline & Encore & 724 & $899 *$ & 7,4 & $3,4 *$ & 55.7 & $90.0 * *$ & 38.5 & 40.4 NS & 6.2 & $8.8 \mathrm{NS}$ & 11.8 & $9.4 *$ \\
\hline & Wilking & 439 & $754 *$ & 17,5 & $8,1 * *$ & 57.8 & $94.7 * *$ & 9.0 & $9.7 \mathrm{NS}$ & 26.5 & $5.6 * *$ & 7.7 & $8.3 \mathrm{NS}$ \\
\hline & Hernandina & 239 & $462 *$ & 15,6 & $38,7 *$ & 195.4 & $229.9 \mathrm{NS}$ & 15.2 & $14.6 \mathrm{NS}$ & 12.4 & $17.1 *$ & 7.5 & $6.3 \mathrm{NS}$ \\
\hline & Nules & 302 & $286 \mathrm{NS}$ & 18,1 & $25,2 \mathrm{NS}$ & 46.0 & $64.2 \mathrm{NS}$ & 7.7 & $11.2 \mathrm{NS}$ & 10.6 & $5.4 \mathrm{NS}$ & 12.1 & $8.3 \mathrm{NS}$ \\
\hline & Fina & 338 & $510 * *$ & 38,4 & $56,4 *$ & 112.7 & $138.1 \mathrm{NS}$ & 35.9 & 50.0 ** & 15.3 & $23.9 * *$ & 13.7 & $17.7 \mathrm{NS}$ \\
\hline & Setubalense & 34 & $78 \mathrm{NS}$ & 24,5 & $23,6 \mathrm{NS}$ & 59.4 & $73.3 \mathrm{NS}$ & 53.9 & 46.6 NS & 10.2 & 17.4 NS & 6.4 & $6.6 \mathrm{NS}$ \\
\hline \multirow{6}{*}{ 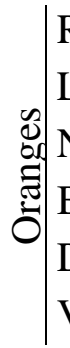 } & Rohde & 477 & $788 \mathrm{NS}$ & 41,5 & $66,8 \mathrm{NS}$ & 116.6 & $57.7 * *$ & 12.2 & $19.9 *$ & 19.8 & $31.1 \mathrm{NS}$ & 8.8 & $6.8 \mathrm{NS}$ \\
\hline & Lanelate & 402 & $632 *$ & 33,8 & $35,2 \mathrm{NS}$ & 90.7 & $89.1 \mathrm{NS}$ & 36.9 & $48.4 \mathrm{NS}$ & 18.9 & $25.3 \mathrm{NS}$ & 10.5 & $13.4 \mathrm{NS}$ \\
\hline & Newhall & 1199 & $1110 \mathrm{NS}$ & 50,8 & $44,7 \mathrm{NS}$ & 23.2 & $72.2 * *$ & 37.8 & $56.5 \mathrm{NS}$ & 33.7 & $33.9 \mathrm{NS}$ & 15.6 & $12.0 \mathrm{NS}$ \\
\hline & Baía & 633 & 797 NS & 35,9 & $57,4 *$ & 45.8 & $53.7 \mathrm{NS}$ & 18.8 & $48.3 *$ & 28.1 & $30.9 \mathrm{NS}$ & 10.6 & $6.4 \mathrm{NS}$ \\
\hline & Dalmau & 1288 & $1230 \mathrm{NS}$ & 66,6 & $52,6 \mathrm{NS}$ & 35.0 & $67.7 * *$ & 38.7 & $48.4 *$ & 44.6 & $29.6 * *$ & 16.2 & $19.0 \mathrm{NS}$ \\
\hline & Valencia late & 891 & $968 \mathrm{NS}$ & 82,0 & $86,0 * *$ & 142.0 & $124.0 *$ & 36.0 & $30.0 * *$ & 26.0 & $26.0 \mathrm{NS}$ & 24.0 & $16.0 * *$ \\
\hline \multicolumn{2}{|c|}{ Lemon 'Lisbon' } & 3801 & 3614 NS & 5.9 & 10.4 NS & 59.4 & 116.7 N.S. & 17.2 & 10.6 NS & 6.0 & $21.7 * *$ & 0.0 & $0.3 \mathrm{NS}$ \\
\hline \multicolumn{2}{|c|}{ Average } & 772 & 896 ** & 32.4 & $40.6^{* *}$ & 91.2 & $117.6 * *$ & 28.2 & 32.0 ** & 19.6 & $21.7 * *$ & 12.2 & $10.3^{* *}$ \\
\hline
\end{tabular}

(1) Level of Significance: NS - Non significant; * - Significant difference at $\mathrm{P} \leq 0.05$; ** - Significant difference at $\mathrm{P} \leq 0.01$. 